\title{
Prevalence of Oral Mucosal Lesions in a Tertiary Care Dental Hospital of Kathmandu
}

\author{
Dipshikha Bajracharya, ${ }^{1}$ Sujaya Gupta, ${ }^{2}$ Bidhata Ojha, ${ }^{1}$ Radha Baral' \\ 'Department of Oral and Maxillofacial Pathology, Kantipur Dental College and Teaching Hospital, Kathmandu, Nepal, \\ ${ }^{2}$ Department of Periodontics, Kantipur Dental College and Teaching Hospital, Kathmandu, Nepal.
}

\section{ABSTRACT}

Introduction: Oral mucosa can be affected by a variety of soft tissue lesions and conditions. Benign as well as malignant lesions of oral cavity are common. Squamous cell carcinoma is one of the commonest malignancies. The present retrospective study was undertaken to study the prevalence of various oral mucosal lesions in a tertiary care dental hospital of Kathmandu.

Methods: This retrospective study was carried out in the Department of Oral and Maxillofacial Pathology at Kantipur Dental College and Teaching hospital from January 2015 to January 2017. The study included biopsy specimen from the oral cavity. The parameters included in the study were age, gender, site of the lesion and histopathological diagnosis. The data collected was statistically analyzed.

Results: A total of 111 biopsy cases were included in the present study. Out of which, there was 16 $(14.4 \%)$ cases of non-neoplastic and $16(14.4 \%)$ cases of benign pathology. The oral cavity lesions were commonly seen in age range between 6-74 years where males 59 (53.2\%) were mostly affected. The most common site for oral lesion was buccal mucosa 23 (20.7\%) and anterior gingiva $23(20.7 \%)$. Total $15(13.5 \%)$ cases of oral squamous cell carcinoma were seen as the predominant malignancy affecting in the vestibular region $8(7.2 \%)$.

Conclusions: The present study shows benign as well as the non-neoplastic lesions were more prevalent in oral mucosa with the buccal mucosa and anterior gingiva as the commonest site of occurrence.

Keywords: benign; malignant; non-neoplastic; oral mucosal lesion.

\section{INTRODUCTION}

Oral mucosa provides a defensive mechanism against various microbial pathogens, trauma as well as carcinogens. It can be affected by a variety of soft tissue lesions and conditions. ${ }^{1}$ In the oral cavity benign lesions are commonly observed but we cannot neglect the fact that Squamous cell carcinoma is the most common malignancy affecting the site.

Oral mucosal lesions are usually mystified by their etiology which may be viral, fungal, bacterial, any habits related or may even be without definite etiology. Hence, it is of utmost importance to have knowledge regarding the lesions that occur in the oral mucosa. ${ }^{2}$ Understanding of the prevalence of the oral mucosal lesions may facilitate in the prevention, appropriate diagnosis and prompt treatment of the disease.

Correspondence: Dr. Dipshikha Bairacharya, Department of Oral and Maxillofacial Pathology, Kantipur Dental College and Teaching hospital, Basundhara, Kathmandu, Nepal. Email: drdipshikhabaj@gmail. com, Phone: +977-9860536501. 
The present retrospective study was carried out in the tertiary care dental hospital to assess the pattern of various oral soft tissue lesions in Kathmandu valley.

\section{METHODS}

This retrospective cross-sectional observational study was carried out in the Department of Oral and Maxillofacial Pathology, Kantipur Dental College and Teaching hospital from January 2015 to January 2017. Institutional ethical committee approval was taken before conducting the study from IRC-KDCTH. Findings of clinical history and physical examination were noted from patient's record book that had the recordings of biopsy examination. The parameters included in the study were age, gender, site and histopathological diagnosis of the lesion. ${ }^{3}$ Repeat biopsy for residual lesion, odontogenic cysts and tumors were excluded from the study. A total of number of cases was selected based on convinience sampling method. Frequency analysis was done for the entire cases recorded using SPSS version 20 .

\section{RESULTS}

A total of 111 biopsy cases were recorded in the present study. 45 (54.3\%) cases were neoplastic and 38 (45.7) cases were non-neoplastic (Table 1). 16 (14.4\%) cases of oral fibroma have been reported as the most common benign pathology. Total $16(14.4 \%)$ cases of pyogenic granuloma was the common non neoplastic lesion whereas squamous cell carcinoma was the commonest malignant lesion 15 (13.5\%) (Table 2).

\begin{tabular}{|l|l|}
\hline $\begin{array}{l}\text { Table 1. Frequency distribution of neoplastic and } \\
\text { non-neoplastic oral mucosal lesions. }\end{array}$ \\
\hline Category & $\mathbf{n}(\%)$ \\
\hline Neoplastic & $45(54.3)$ \\
Non-neoplastic & $3845.7)$ \\
Total & $83(100)$ \\
\hline
\end{tabular}

The age ranged from 6 to 74 years with the mean age $\pm S D=40.02 \pm 15.6$. The youngest case was of a six year old female child diagnosed with hyper plastic epithelium of tongue and the oldest one was 74 years old female patient diagnosed with Adenoid cystic carcinoma of palate (Figure 1). Correlation of the malignant lesions with the age showed squamous cell carcinoma (SCC) to be the most prevalent in age group of 51 - 60 years (Table 3 ).

Out of total 111 cases, 59 (53.2\%) consisted of males whereas $52(46.8 \%)$ were females with the male to female ratio of 1.25:1 (Figure 2). Correlation of sex with malignant lesions revealed male $10(9 \%)$ to be predominantly affected by squamous cell carcinoma compared to females.

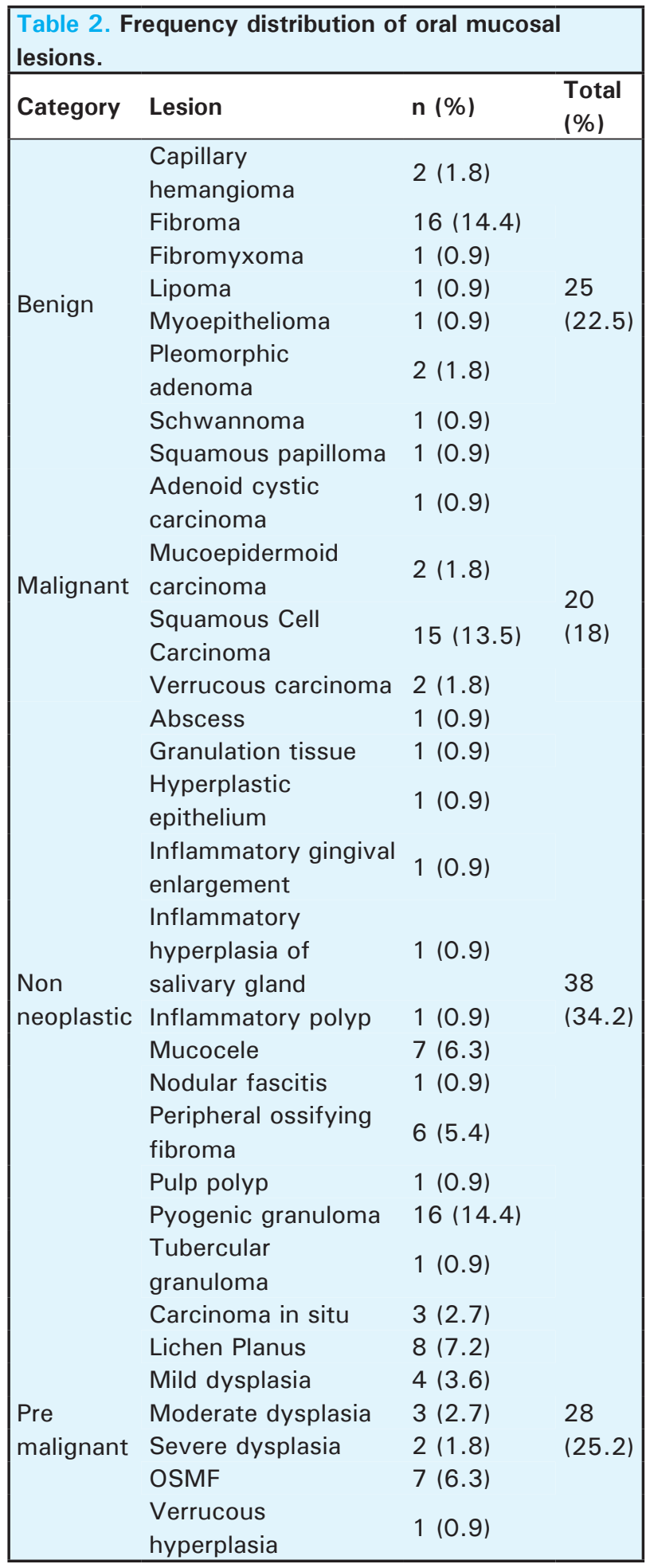



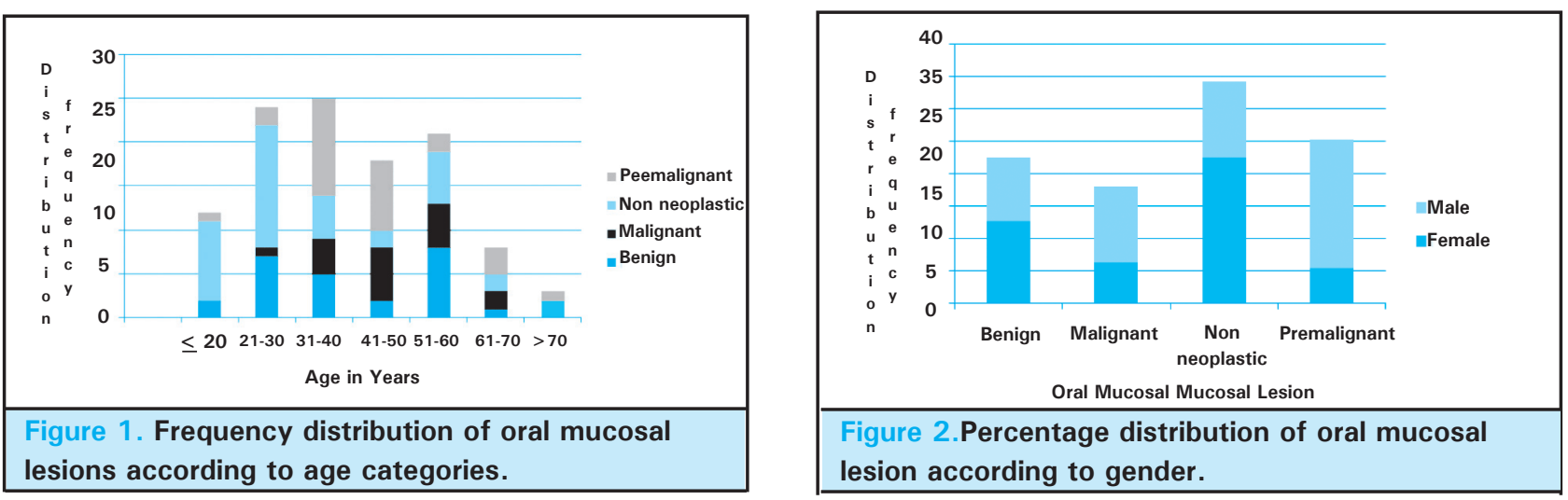

\begin{tabular}{|c|c|c|c|c|c|}
\hline \multirow[b]{2}{*}{ Age (years) } & \multicolumn{4}{|c|}{ Malignancy } & \multirow[b]{2}{*}{ Total } \\
\hline & $\begin{array}{l}\text { Adenoid cystic } \\
\text { carcinoma } \\
\text { Frequency }(\%)\end{array}$ & $\begin{array}{l}\text { Mucoepidermoid } \\
\text { carcinoma } \\
\text { Frequency (\%) }\end{array}$ & $\begin{array}{l}\text { Squamous cell } \\
\text { carcinoma } \\
\text { Frequency (\%) }\end{array}$ & $\begin{array}{l}\text { Verrucous } \\
\text { Carcinoma } \\
\text { Frequency (\%) }\end{array}$ & \\
\hline$\leq 20$ & - & - & - & - & - \\
\hline $21-30$ & - & - & $1(0.9)$ & - & $1(0.9)$ \\
\hline $31-40$ & - & $1(0.9)$ & $2(1.8)$ & $1(0.9)$ & $4(3.6)$ \\
\hline $41-50$ & - & $1(0.9)$ & $4(3.6)$ & $1(0.9)$ & $6(5.4)$ \\
\hline $51-60$ & - & - & $5(4.5)$ & - & $5(4.5)$ \\
\hline $61-70$ & - & - & $2(1.8)$ & - & $2(1.8)$ \\
\hline$>70$ & $1(0.9)$ & - & $1(0.9)$ & - & $2(1.8)$ \\
\hline Total & $1(0.9)$ & $2(1.8)$ & $15(13.5)$ & $2(1.8)$ & $20(18)$ \\
\hline
\end{tabular}

Table 4. Site distribution of oral mucosal lesions.

\begin{tabular}{|c|c|c|c|c|c|}
\hline \multirow[b]{2}{*}{ Site } & \multicolumn{4}{|c|}{ Neoplasm Type } & \multirow[t]{2}{*}{ Total } \\
\hline & $\begin{array}{l}\text { Benign } \\
\text { n (\%) }\end{array}$ & $\begin{array}{l}\text { Malignant } \\
\text { n (\%) }\end{array}$ & $\begin{array}{l}\text { Nonneoplastic } n \\
(\%)\end{array}$ & $\begin{array}{c}\text { Premalignant } \\
\text { n (\%) }\end{array}$ & \\
\hline Anterior Gingiva & $4(3.6)$ & - & $17(15.3)$ & $2(1.8)$ & $23(20.7)$ \\
\hline Buccal mucosa & $7(6.3)$ & $2(1.8)$ & - & $14(12.6)$ & $23(20.7)$ \\
\hline Gingival sulcus & - & $1(0.9)$ & - & - & $1(0.9)$ \\
\hline Lower lip & $2(1.8)$ & - & $8(7.2)$ & $1(0.9)$ & $11(9.9)$ \\
\hline Palate & $4(3.6)$ & $2(1.8)$ & $2(1.8)$ & $1(0.9)$ & $9(8.1)$ \\
\hline $\begin{array}{l}\text { Posterior extraction } \\
\text { socket }\end{array}$ & - & - & $2(1.8)$ & - & $2(1.8)$ \\
\hline Posterior gingiva & $2(1.8)$ & - & $8(7.2)$ & - & $10(9)$ \\
\hline Retromolar trigone & $2(1.8)$ & $2(1.8)$ & - & - & $4(3.6)$ \\
\hline Tongue & $1(0.9)$ & $5(4.5)$ & $1(0.9)$ & $2(1.8)$ & $9(8.1)$ \\
\hline Upper Lip & $3(2.7)$ & - & - & - & $3(2.7)$ \\
\hline Vestibule & - & $8(7.2)$ & - & $8(7.2)$ & $16(14.4)$ \\
\hline Total & $25(22.5)$ & $20(18)$ & $38(34.2)$ & $28(25.2)$ & $111(100)$ \\
\hline
\end{tabular}


Among the sites involved by various oral mucosal lesions anterior gingiva $23(20.7 \%)$ and buccal mucosa $23(20.7 \%)$ was the commonest site (Table 4$)$. About $7(6.3 \%)$ cases of benign lesions mostly involved the buccal mucosa whereas malignant lesions were commonly seen in vestibular region $8(7.2 \%)$.

\section{DISCUSSION}

This retrospective study was done to assess the pattern of oral mucosal lesions among the biopsy specimen. There was total of 111 oral mucosal lesions received during the study period. Among the different lesions prevalence of non-neoplastic lesion was more compared to neoplastic and premalignant lesions which was similar to the study done by Mehrotra et al, ${ }^{4}$ in India.

In our study the patients were aged ranging from 6-74 years with the mean of 40.02. Oral mucosal lesions was found to be highly prevalent in age range of 31-40 years comparable to study done by Pudasaini et al, ${ }^{5}$ and AlKhateeb ${ }^{6}$ where majority of lesions were seen from $2^{\text {nd }}$ to $4^{\text {th }}$ decade. Only 12 cases reported in individuals aged below 20 years mostly having benign or inflammatory pathology with a single case of premalignant lesion which was similar to Modi et $\mathrm{al}^{7}$ and Claudia et ${ }^{7},{ }^{8}$ which may be due to the developmental anomalies or underlying inflammatory etiology. In our study the peak age of incidence for malignant lesion was found to be between 41-50 years comparable to the findings of the study done by Saraswathi et al, ${ }^{9}$. In their study it was stated that the habit of tobacco usage was highest among the age group of 20 to 50 years which might be the reason for the incidence.

In our study, oral mucosal lesions were found to be more prevalent in males. Chiefly the malignant as well as the premalignant lesions were more in males compared to females similar to the study done by Pudasaini et al, ${ }^{10}$ and Agrawal $\mathrm{R}$ et $\mathrm{al},{ }^{3}$ which may be mainly attributed to the oral habits in males.
Regarding the most common site for oral mucosal lesion anterior gingiva and buccal mucosa was found to be frequently affected which was similar to findings by M. Ali et al, ${ }^{1}$ wherein more than half the lesions were in buccal mucosa. In our study, pyogenic granuloma accounted for the commonest non-neoplastic lesion in anterior gingiva which may be the reason for anterior gingiva being the equally common site.

The prevalence of Squamous cell carcinoma in our study was $13.5 \%$ which was higher than the study done by Gambhir et al, ${ }^{10}$. In our study the common site for SCC was vestibule unlike the study done by Modi et al, ${ }^{7}$ and Mehrotra et al, ${ }^{4}$ wherein tongue was the common site. This variation in the prevalence and the site of SCC may be due to demographic difference as well as divergence in food habits and other deleterious oral habits.

The data in this study is from a single institution so it may have some limitations. Hence a multi-centric data with larger sample size for longer duration may overcome this limitation.

\section{CONCLUSIONS}

The present study shows that neoplastic lesions were more prevalent than non-neoplastic in oral mucosa with benign lesions being more common. Buccal mucosa and anterior gingiva was the most prevalent site of occurrence of oral lesions with high prevalence in middle age group.

\section{ACKNOWLEDGEMENTS}

We would like to acknowledge Kantipur Dental College, Dr. Amir Bajracharya, Dr. Bhageshwar Dhami and Dr. Parajeeta Dikshit, Dr. Senchhema Limbu and Dr. Sourabh Roy.

Conflict of Interest: None.

\section{REFERENCES}

1. Ali M, Joseph B, Sundaram D. Prevalence of oral mucosal lesions in patients of the Kuwait University Dental Center. Saudi Dent J. 2013 Jul;25(3):111-8. [PubMed | DOI | Full text]

2. Prasad KV, Javali SB, Rajesh G, Jithendra A. An epidemiological study of oral mucosal lesions in Karnataka State, India. J Indian Acad Oral Med Radiol. 2004 Jan 1;16(1):9-18. [Full text]
3. Agrawal R, Chauhan A, Kumar P. Spectrum of Oral Lesions in A Tertiary Care Hospital. J Clin Diagn Res. 2015 Jun;9(6):EC11-3. [PubMed | Full text]

4. Mehrotra R, Pandya S, Chaudhary AK, Kumar M, Singh M. Prevalence of oral pre-malignant and malignant lesions at a tertiary level hospital in Allahabad, India. Asian Pac J Cancer Prev. 2008 Jan 1;9(2):263-5.[PubMed | Full text] 
5. Pudasaini S, Baral R. Oral cavity lesions: A study of 21 cases. Journal of Pathology of Nepal. 2011;1(1):49-51. [Full text]

6. Al-Khateeb TH. Benign oral masses in a northern Jordanian population-a retrospective study. Open Dent J. 2009 Jul 28;3:147-53. [PubMed | DOI |Full text]

7. Modi D, Laishram RS, Sharma LD, Debnath K. Pattern of oral cavity lesions in a tertiary care hospital in Manipur, India. J Med Soc. 2013 Sep 1;27(3):199-202.[Full text]

8. Claudia F G, Marqués NA, Berini-Aytés L, Gay-Escoda C. Prevalence of biopsied oral lesions in a Department of Oral Surgery (2007-2009). J Clin Exp Dent 2011;3:e73-7.[Full text]
9. Saraswathi TR, Ranganathan K, Shanmugam S, Sowmya R, Narasimhan PD, Gunaseelan R. Prevalence of oral lesions in relation to habits: Cross-sectional study in South India. Indian J Dent Res. 2006 Jul-Sep;17(3):121-5. [PubMed | Full text]

10. Gambhir RS, Veeresha KL, Sohi R, Kakkar H, Aggarwal A, Gupta D. The prevalence of oral mucosal lesions in the patients visiting a dental school in Northern India in relation to sex, site and distribution: A retrospective study. J Clin Exp Dent 2011;3:e10-7. [Full text] 